\title{
Surgical treatment of chest deformities
}

\author{
Azat Satzhanov ${ }^{1}$, Marat Rabandiyarov ${ }^{1}$, Bolat Nagimanov ${ }^{2}$
}

\author{
${ }^{1}$ Zhambyl Regional Children's Hospital \\ ${ }^{2}$ Corporate fund "University Medical Center" National \\ Research Center for Maternal and Child Health, Astana, \\ Kazakhstan
}

This work is licensed under a Creative Commons Attribution 4.0 International License
J CLIN MED KAZ 2017; 3(45 SUPPL 3):22-24 Автор для корреспонденции: Сатжанов А.Б., «Жамбылская областная детская больница», Адрес: мкр. Байтерек, 1, г. Тараз, Казахстан, +77077926699 azat_sat@mail.ru

\section{ABSTRACT}

The purpose of the study: evaluation of clinical outcomes after thoracoplastic operations, including D. Nass in children with various forms of chest deformities.

Methods: 28 thoracoplastic surgeries were performed on the basis of the Zhambyl Regional Children's Hospital from 2015, and 3 of them in cooperation with specialists from the UMC "NSMC". By sexual ratio, boys prevailed $(1: 3,6)$. According to the types of deformities $55.6 \%$ of the pectus excavatum, $21.4 \%$ of the Poland syndrome, $14 \%$ of the pectus carinatum. All the children underwent radiological studies: radiography, CT with the definitions of the Gyzick and Haller indexes.

Results: Indication for an operative intervention with a funnel-shaped cosmetic defect of the chest, the Haller index is more than 3.25; the Gizyck index is less than 0.65 . The average duration of operations was $56.39 \pm 1.40 \mathrm{~min}$, the time spent in the intensive care unit was $1.14 \pm 0.12$ days, and the time spent in the pediatric orthopedics department was $12.35 \pm 1.15$ days. Based on the results of IG in the pre-operative period averaged 0.59 , after the operation the mean IG increased to 1.00, which shows a correction of the chest. Differences of IG in the preoperative and postoperative periods demonstrate an increase in the IG index by an average of $85.0 \%$ of the initial.

Conclusions: According to our observations, the results of D. Nass's operation under endovision, in the postoperative period, show good and satisfactory results to $85 \%$ of cases, with a low risk of complications. When fixing the plate, it is recommended to strictly observe the operating technique: epipleural implant insertion, blockage of the ends with short transverse plates, which contributes to the stability of the metal structure.

Key words: thoracic deformation, thoracoplasty, D. Nass operation.

\section{ТҰЖЫРЫМДАМА}

\section{КЕУДЕ ҚУЫСЫ ДЕФОРМАЦИЯСЫНЫН ХИРУРГИЯЛЫҚ ЕМІ}

Сатжанов А.Б. ${ }^{1}$, Рабандияров М.Р. ${ }^{1}$, Нагыманов Б.А. ${ }^{2}$

${ }^{1}$ Жамбыл областық балалар ауруханасы

2 «UMC» корпоративтік қорының Ана мен бала ұлттық ғылыми орталығы, Астана, Қазақстан

Зерттеменің мақсаты: балалардағы кеуде қуысы түрлі деформациясының торакопластикалық отадан кейінгі және Д.Насс әдісін қолданғаннан кейінгі клиникалық нәтижелерді бағалау.

Әдістері: 2015 жылдан бері ЖОБА 28 торакопластикалық ота жасалынды, оның 3-і АБҰҒО мамандарымен бірлесіп жүргізілді. Жынысына байланысты ұлдар басым болды (1:3,6). Көкірек деформация түрлері бойынша 55,6\% құйғы тәріздес, Полланд синдромымен 21,4\%, құc-төстер 14\% құрады. Барлық балалар радиологиялық зерттеулерден өтті: рентгенография, компьютелтік томография, Гижицк және Галлер индекстерінің анықтауымен.

Нәтижелері: Кеуденің құйғы тәрізді деформациясына оперативті емге араласу көрсеткіші болып табылады: косметикалық ақау, Галлер индексі 3,25-тен артық; Гижицк индексі 0,65-тен аз болған жағдайларда. Операциялардың орташа ұзақтығы $56.39 \pm 1.40$ мин, реанимация бөлімінде өткізілген уақыт $1.14 \pm 0.12$ күн, ортопедия бөлімінде өткізілген уақыт $12.35 \pm 1.15$ күн болды. ГИ нәтижелеріне сүйене отырып, операцияға дейін орташа есеппен 0,59 , ал отадан кейін ГИ орташа 1.00 дейін өсті. Алдын ала операциядан кейінгі және операциядан кейінгі кезеңдегі IG айырмашылығы IG индексінің орташа мәнін бастапқы 85,0\% -ға арттырады.

Қорытынды: Біздің байқауымыз бойынша Д.Насс операциясынан кейін 85\% жағдайда жақсы және қанағаттанарлық нәтижелер көрсетілді, асқыну қаупі аз. Пластинаны бекітіп жатқанда, қолданыстағы техниканы қатаң сақтаған жөн: имплантатты эпиплевральды енгізу, металл конструкциясының тұрақтылығын қамтамасыз ететін қысқа көлденең пластиналарды пайдалану.

Түйінді сөздер: кеуде деформациясы, торакопластика, Д. Насс тәсілі. 


\section{РЕЗЮME}

ХИРУРГИЧЕСКОЕ ЛЕЧЕНИЕ ДЕФОРМАЦИЙ ГРУДНОЙ КЛЕТКИ

Сатжанов А.Б. ${ }^{1}$, Рабандияров М.Р. ${ }^{1}$, Нагыманов Б.А. ${ }^{2}$

Жамбылская областная детская больница, отделение ортопедии

отделение ортопедии №1, Национальный научный центр материнства и детства корпоративного фонда «UMC», г. Астана, Казахстан

Цель исследования: оценка клинических результатов после торакопластических операций, в том числе и по Д.Нассу у детей при различных формах деформациях грудной клетки

Методы: На базе ЖОДБ с 2015 года были проведены 28 торакопластических операций, из них 3 совместно со специалистами с ННЦМД. По половому соотношению мальчики превалировали (1:3,6). По видам деформаций 55,6\% ВДГК, 21,4\% синдром Поланда, 14\% с КДГК. Все дети проходили радиологические исследования: рентгенография, КТ с определениями индекса Гижицкой, Галлера.

Результаты: Показанием для проведения оперативного вмешательства при воронкообразной косметический дефект грудной клетки, индекс Галлера больше 3,25; индекс Гижицкой менее 0,65. Средняя продолжительность операций составила 56,39 $\pm 1,40$ мин, время пребывания в реанимационном отделении - 1,14 $\pm 0,12$ дня, время пребывания в отделении детской ортопедии $-12,35 \pm 1,15$ дней. По результатам ИГ в дооперационном периоде составлял в среднем 0,59, после операции средний показатель ИГ возрос до 1,00, что показывает коррекцию грудной клетки. Различия ИГ в дооперационном и послеоперационном периодах демонстрируют увеличение показателя ИГ в среднем на $85,0 \%$ от первоначального.

Выводы: По нашим наблюдениям, результаты операции Д.Насса под эндовидеоассистенцией, в послеоперационном периоде показывает хорошие и удовлетворительные результаты до 85 \% случаев, с низким риском развития осложнений. При фриксации пластины рекомендуется строго соблюдать операционную технику: эпиплевральное введение импланта, блокирование концов короткими поперечными пластинами, что способствует к стабильности металлоконструкции.

Ключевые слова: деформация грудной клетки, торакопластика, операция Д. Насса.

\section{Введение}

Деформация распространенная грудной клетки врожденная
(ВДГК) - наиболее аномалия грудной клетки, с частотой 1-8 из 1000 живоноворожденных и распространенностью $2,6 \%$ у детей в возрасте от 7 до 14 лет. ВДГК составляет $90 \%$ всех деформаций грудной клетки и в 5 раз чаще встречаются у мальчиков. Депрессия грудной клетки является главным признаком ВДГК. Соображения в отношении лечения выходят далеко за рамки эстетики, так как ВДГК может влиять на самооценку ребенка и приводить к социальной изоляции. В зависимости от тяжести заболевания пациенты могут сообщать о боли в области передней и левой парастернальной области, одышке при нагрузке и о снижении сердечно-легочной выносливости, все это можно исправить с помощью операции. Сердечная оценка важна по нескольким причинам, включая тот факт, что у части пациентов может быть аномально расположен или частично сжатое сердце из-за деформации. В редких случаях ВДГК может сигнализировать о наличии основного заболевания соединительной ткани, такого как синдром Марфана, синдром Лойса-Дитца.

Целью настоящей работы: оценка клинических результатов после выполнения торакопластических операций, в том числе и по Д.Нассу у детей при различных формах деформации грудной клетки.

\section{Материалы и методы}

В ГКП на ПХВ «Жамбылская областная детская больница» совместно с ННЦМД с 2015 года торакопластические операции были проведены 28 пациентам в возрасте до 10-ти лет - 16 (57\%) и старше 10 лет - 12 (43\%). Отмечено, что прооперировано девочек $6(21 \%)$ и мальчиков $22(79 \%)$. По наличиям деформациям грудной клетки у 18 $(55,6 \%)$ воронкообразная деформация, у 6 синдром Поланда, а у 4 детей килевидная деформация грудной клетки. Всем детям были проведены рентгенологические, КТ, спирографическое исследование. В программу обследования входили: рентген в $2 \mathrm{x}$ проекциях грудной клетки с определением индекса Гижицкой, KT в 3D реконструкции с визуализацией хрящевых тканей с определением индекса Галлера, спирография, определения функции внешнего дыхания. Воронкообразные деформации грудной клетки классифицировались по Парку, по структуре расположились так: IA тип у - 16 пациентов, IB тип у -4 ребенка, IIA1 тип у -6 , IIA2 тип - 2 ребенка.

\section{Результаты и обсуждения}

Всем детям после предварительной подготовки применялись различные методики корригирующей и косметической торакопластики, в том числе операция Насса, как малоинвазивное корригирующее вмешательство. Показанием для проведения оперативного вмешательства при воронкообразной косметический дефект грудной клетки, индекс Галлера больше 3,25; индекс Гижицкой менее $0,65$.

Средняя продолжительность операций составила 56,39 $\pm 1,40$ мин, время пребывания в реанимационном отделении - 1,14 \pm 0,12 дня, время пребывания в отделении детской ортопедии - 12,35 $\pm 1,15$ дней. Самым серьезным осложнением операции Насса является прямая сердечная травма, которой у нас не наблюдалось. В послеоперационном периоде осложнения наблюдались у 2 пациентов (14,3 \%), по одному случаю пришлось смещение импланта вверх $(7,1 \%)$ без потери коррекции и на гемоторакс (7,1%). Результаты, демонстрируют, что ИГ в дооперационном периоде составлял в среднем 0,59. После операции средний показатель ИГ возрос до 1,00, что показывает коррекцию грудной клетки. Различия ИГ в дооперационном и послеоперационном периодах демонстрируют увеличение показателя ИГ в среднем на 85,0\% от первоначального.

В послеоперационном периоде все дети получали симптоматическое лечение, антибиотикопрофилактику, физиолечение, дыхательная гимнастика, ЛФК. Показанием к выписке являлось стабилизация общего состояния (отсутствие болевого синдрома, улучшение общего самочувствия), коррекция грудной клетки, удовлетворительные данные контрольной рентгенограммы, где отмечалось стабильность металлоконструкций, заживление послеоперационной раны первичным натяжением.

\section{Выводы}

Наши исследования, посвященные изучениям результатов торакопластических операций и операции Насса под эндовидеоассистенцией, демонстрируют в послеоперационном периоде хорошие и удовлетворительные результаты практически в 85,7 \% случаев, с низким риском развития осложнений. Процедура Насса приводит к меньшему количеству рубцов, и доказательства указывают на более низкий риск инфицирования и кровотечения по сравнению с иными техниками. Данный вид торакопластики хорошо переносится пациентами и характеризуется короткими сроками госпитального периода и реабилитации. При фиксации пластины рекомендуется строго соблюдать операционную технику: эпиплевральное введение импланта, блокирование концов короткими поперечными пластинами, что приводит к стабильности металлоконструкции. 


\section{Литература}

1. Jaroszewski D, Notrica D, McMahon L, Steidley DE, Deschamps C. Current management of pectus excavatum: a review and update of therapy and treatment recommendations. J Am Board Fam Med. 2010;23(2):230-239. doi:10.3122/jabfm.2010.02.090234

2. Nuss D, Obermeyer RJ, Kelly RE Jr, . Pectus excavatum from a pediatric surgeon's perspective. Ann Cardiothorac Surg. 2016;5:493-500. doi:10.21037/acs.2016.06.04

3. Kelly RE Jr, Mellins RB, Shamberger RC, et al. Multicenter study of pectus excavatum, final report: complications, static/exercise pulmonary function, and anatomic outcomes. J Am Coll Surg. 2013;217(6):1080-1089. doi:10.1016/j.jamcollsurg.2013.06.019

4. Jo WM, Choi YH, Sohn YS, Kim HJ, Hwang JJ, Cho SJ. Surgical treatment for pectus excavatum. J Korean Med Sci. 2003;18(3):360-364. doi:10.3346/jkms.2003.18.3.360

5. Sacco Casamassima MG, Goldstein SD, Salazar JH, McIltrot KH, Abdullah F, Colombani PM. Perioperative strategies and technical modifications to the Nuss repair for pectus excavatum in pediatric patients: a large volume, single institution experience. J Pediatr Surg. 2014;49 (4): 575-582. doi:10.1016/j.jpedsurg.2013.11.058 